\title{
The structure of mycelial cords and rhizomorphs of fungi: A mini- review
}

\section{Yafetto L}

Department of Molecular Biology and Biotechnology, School of Biological Sciences, College of Agriculture and Natural Sciences, University of Cape Coast, Cape Coast, Ghana

Yafetto L 2018 - The structure of mycelial cords and rhizomorphs of fungi: A mini-review. Mycosphere 9(5), 984-998, Doi 10.5943/mycosphere/9/5/3

\begin{abstract}
Fungi are ubiquitous - they are found in any conceivable environment, i.e., both aquatic and terrestrial habitats. They remain one of the most diverse groups of organisms on Earth. Because fungi are heterotrophic, they obtain their nutrients by colonizing their substrates with a vegetative mass of hyphae called mycelium. These hyphae secrete enzymes that digest nutrients locked in colonized substrates, after which the nutrients are then absorbed by the hyphae. Not only do hyphae constitute the mycelium of fungi, but they also form other structures - mycelial strand, mycelial cords, and rhizomorphs - through which fungi are able to spread in their environment in search of new substrates to colonize. The aim of this present paper is to explore the structure of mycelial cords and rhizomorphs. Rhizomorphs are among the most complex organs produced by fungi. They are root-like structures constituted by a series of differentiated tissues each with distinctive hyphal type, orientation, size, and function. Thus, rhizomorphs are produced as a result of a coordinated growth of millions of bundled hyphae. Rhizomorph-forming fungi thrive in nutrient-poor environment and are known to cause devastating destruction to homes and plantations. Because rhizomorphs serve as exploratory organs, and they enhance the survival of rhizomorph-forming fungi in plantations and homes, farmers, homeowners, attorneys, and even mycologists and plant pathologists, need to understand and appreciate their potential to wreak havoc that results in huge annual financial losses.
\end{abstract}

Key words - Armillaria spp - fungal hyphae - Meruliporia incrassata - mycelial cord rhizomorph structure - Serpula lacrymans

\section{Introduction}

Fungi from the genera Armillaria, Auricularia, Coniophora, Fomitopsis, Meripilus, Meruliporia, Polyporus, and Serpula are well-known wood decomposers (Schmidt 2006). Wooddecay fungi are classified into white rot and brown rot fungi. Although these wood-decay fungi secrete enzymes during growth and colonization of substrates, their ability to decompose wood substrates is attained through both enzymatic and non-enzymatic, chelator-mediated Fenton mechanisms (Eriksson et al. 1990, Highley \& Illman 1991, Ritschkoff et al. 1992, Goodell 2003, Lindahl \& Olsson 2004, Schwarze 2007, Goodell et al. 2017). The absorption of these nutrients sustains vegetative growth and allows an increase in hyphal biomass, which is achieved through tip extension and elaborate branching of the hyphae. This branching hyphal biomass is collectively called mycelium (Carlile 1994). Because fungi use an absorptive mechanism to acquire their 
nutrients, with time, they deplete the nutrients from the colonized substrate, after which they search for new substrates to colonize.

The search for nutrient-rich substrates is accomplished through liberated spores, and the production of mycelial strands, mycelial cords, and rhizomorphs. The constituent mycelia of the strands, cords, and rhizomorphs migrate from nutrient-poor substrates and explore the environment in search of nutrient-rich substrates and as a result translocate nutrients and water towards their tips during migration ((Hartig 1873, Falck 1912, Jennings et al. 1974, Anderson \& Ullrich 1982, Eamus et al. 1985, Granlund et al. 1985, Cairney 1992). During this period of mycelial migration, the hyphae serve as a repository of absorbed nutrients, grow as a cohesive unit, but only lose this cohesive growth when they encounter a suitable substrate and spread out with a characteristic invasive pattern of growth to completely colonize the new substrate (Moore 1994, Money 2004). Apart from mycelial strands, cords, and rhizomorphs, most plants form an association with arbuscular mycorrhizal fungi through which both plants and fungi derive inorganic and organic nutrients from each other (Gerdemann 1968, Mosse 1973, Willis et al. 2012, Lekberg et al. 2015, Brundrett \& Tedersoo 2018).

Since Hartig (1873) described the apical region of rhizomorph of Armillaria mellea (Fig. 1), several studies have highlighted the distribution, structure, and functions of fungal rhizomorphs particularly in Armillaria spp (Granlund et al. 1985, Garrett 1970). For example, Townsend (1954) studied rhizomorph structure in sixteen basidiomycete fungi including Armillaria mellea, Marasmius androsaceus, Merulius lacrymans, and Phallus impudicus. Although the rhizomorph structure of some of these fungi was described, Townsend (1954) acknowledged that other fungi do not produce rhizomorphs in vitro, and further provided some insights into the effects of natural environmental factors on their production in soil or decaying wood. A study by Yafetto et al. (2009) has expanded further the understanding of critical biomechanical attributes of the rhizomorph structure in Armillaria gallica that enhance its exploratory abilities; interestingly the rhizomorph morphology of A. mellea illustrated by Hartig (1873) bears a striking resemblance to that of A. gallica studied by Yafetto et al. (2009) (Fig. 1). The aim of this present paper is to review the structure of mycelial cords and rhizomorphs as agents of spread and infection in plants.
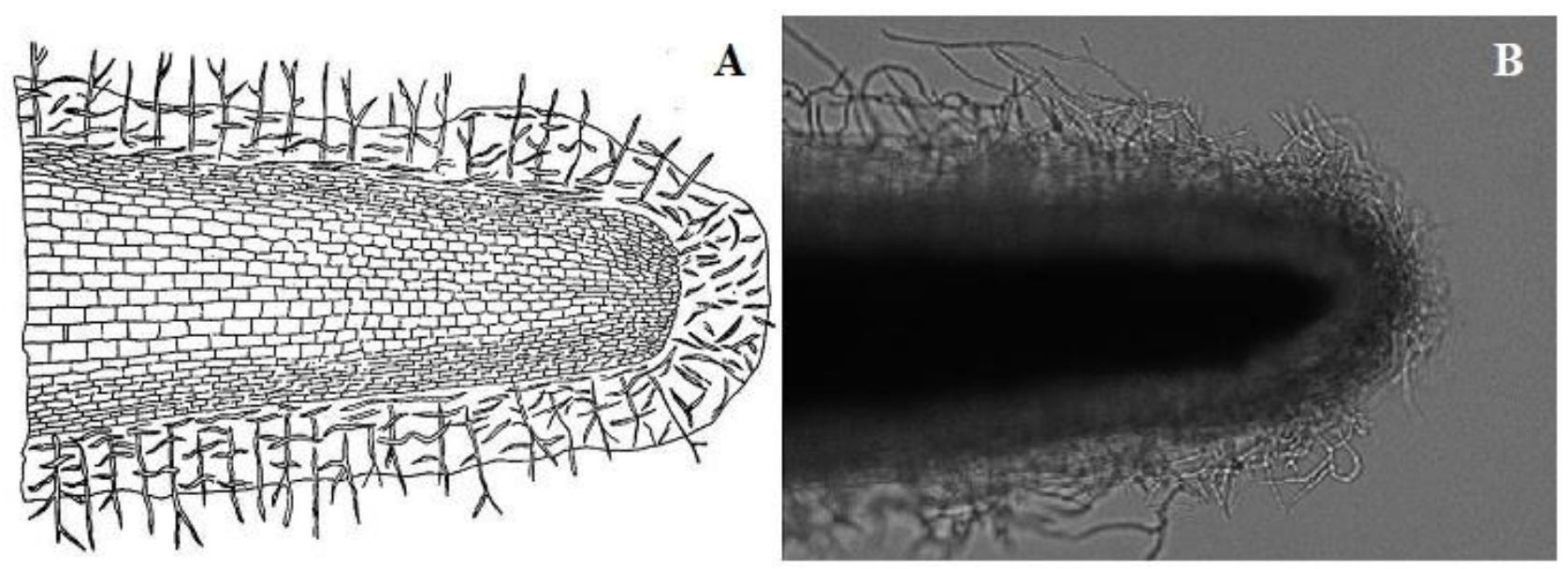

Figure 1 - A Apical region of rhizomorph of Armillaria mellea as described by Hartig (1873); adopted from Garrett (1970). B Apical region of rhizomorph of Armillaria gallica growing in an agar medium (Photo courtesy of L. Yafetto).

\section{Mycelial cords and rhizomorphs}

Hyphae aggregate to serve as building blocks of more complex structures in fungi. These aggregations of fungal hyphae, particularly those formed by basidiomycetes, have been named variously as strands, cords, rhizomorphs, or syrrotia (Rogers \& Watkins 1938, Garrett 1970, Watkinson 1971, Thompson 1984). These terms had been used interchangeably in the literature by mycologists. To solve this situation, Rayner et al. (1985) suggested the adoption of the terms 
mycelial cords and rhizomorphs to denote apically diffuse mycelia aggregates and apically dominant growing tips, respectively. These terms have been readily accepted and been in use since.

Three common constituent hyphal types have been identified in mycelial cords and rhizomorphs: (i) tendril hyphae (or narrow hyphal branches) from the older regions of the main hyphae that interlace around the other hyphae; (ii) central vessel hyphae (wide in diameter and thin-walled); and (iii) thick-walled, but narrow fiber hyphae of old cords that are formed, running longitudinally through a mature cord to provide strength (Nuss et al. 1991).

Mycelial cords and rhizomorphs of wood-decay and pathogenic fungi serve as important sources of inoculum that enable fungi to make an initial contact with newly, yet-to-be-colonized substrates. Although both mycelial cords and rhizomorphs are constructed from hyphae and function in a similar manner, they are structurally different in two respects; first, a mycelial cord is less complex than a rhizomorph; second, a mycelial cord is a linear aggregation of hyphae formed behind an advancing mycelial front where the hyphae are loosely separated and assume a fan-like mat appearance, while a rhizomorph is a complex multicellular root-like organ formed through aggregation, interlacing, and adhesion of scores of hyphae, characterized by a prominently organized tip growth (Yafetto et al. 2009, Watkinson et al. 2016, Fig. 3). The rhizomorph is uniquely characterized by a waterproof surface and a melanized rind that encloses a central open medulla cavity, which serves as a channel for the conduction of water and dissolved nutrients.

Mycelial cords, on one hand, are constituted by hyphae that are relatively loosely aggregated; they develop as a result of adhesion and growth of young branches of hyphae over an older leading hypha, which serves as the building block for the development of the mycelial cord (Moore 1994, Watkinson et al. 2016). Unlike rhizomorphs, mycelial cord formation is considered a secondary process that occurs behind growing hyphal apices distal to the colony margin, and it involves increasing aggregation of hyphae within the aging, mature mycelium (Garrett 1981). During this process of hyphal aggregation, anastomoses between the hyphae on the surface of the cords occur, fusing them into a bundle.

Rhizomorphs, on the other hand, have a similar appearance to the roots of higher plants (Fig. 2). They both function as organs of nutrient and water absorption and translocation, although rhizomorphs can pass also air along their entire lengths to prevent suffocation of the fungus while they explore the anoxic interior of substrates for nutrients (Money 2004, Watkinson et al. 2016). Like the plant roots, rhizomorphs have a highly organized apical growing tip with extreme apical dominance (Fig. 3). This apical region contains a compact growing point of tightly packed hyphae that is protected by a cap of intertwined hyphae in a mucilaginous matrix (Fig. 3). Because of these root-like appearances, rhizomorphs were initially thought to have meristems responsible for organized tip growth similar to the growth mechanism of roots (Garrett 1963, 1970, Rayner et al. 1985). This view of an apically-dominant growing tip of fungal rhizomorphs was erroneous. It is now known that rhizomorphs do not grow as a result of meristematic activity, but rather by extension of the organized apical hyphae (Yafetto et al 2009, Watkinson et al. 2016).

According to Moore (1994), the medullary region behind the tip of a rhizomorph contains vessel hyphae composed of swollen, vacuolated and often multinucleate cells surrounded by copious air- or mucilage-filled spaces. However, other studies have reported wide-lumen vessel hyphae in the medullary region of field-collected rhizomorphs which lack cytoplasmic content, and have suggested further that the major role of these vessel hyphae is for the translocation of nutrients and water over long distance (Eamus et al. 1985, Jennings 1987, Cairney et al. 1988a). Mycelial cords and rhizomorphs in Serpula lacrymans and A. mellea, respectively, have been reported to grow long distances over non-woody, nutrient-poor substrates such as concretes, rocks, metals, tiles, insulation materials (Butler 1957, 1958, Rishbeth 1968, Watkinson 1971, Jennings \& Watkinson 1982, Arora 1986, Jennings 1991, Money 2004).

\section{Mycelial cords of Serpula lacrymans}

The extent to which hyphae are organized and differentiated varies between species (Butler 
1966). Mycelial cords from S. lacrymans (Wulf ex Fr.) Schroet have earlier been reported to be constituted from wide, but empty vessel hyphae and narrow, but thick-walled fiber hyphae running longitudinally through the hyphal aggregate (Hartig \& van Tubeuf 1902, Falck 1912). Hornung \& Jennings (1981) studied the development of surface mycelium of S. lacrymans with emphasis on different stages of growth and observed the following hyphal types: undifferentiated hyphae common to all stages of mycelial development; main hyphae of faster growth rate that have the tendency to form hyphal aggregates; tendril hyphae from which hyphal aggregates originate; fiber hyphae which are often coenocytic, but thick-walled, and vessel hyphae which are often thin-walled with a wide lumen.

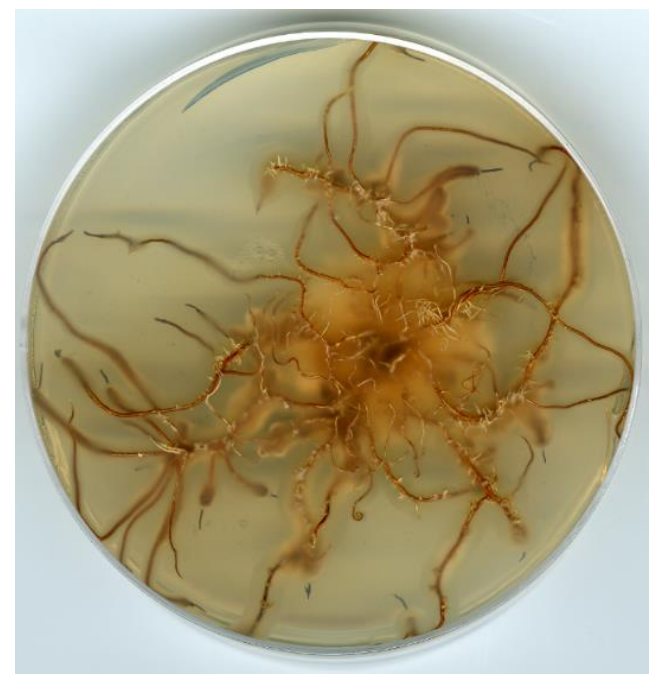

Figure 2 - Root-like structure of Armillaria rhizomorphs in potato dextrose agar medium, after 3 weeks of growth at $30^{\circ} \mathrm{C}$ (Photo courtesy of L. Yafetto).

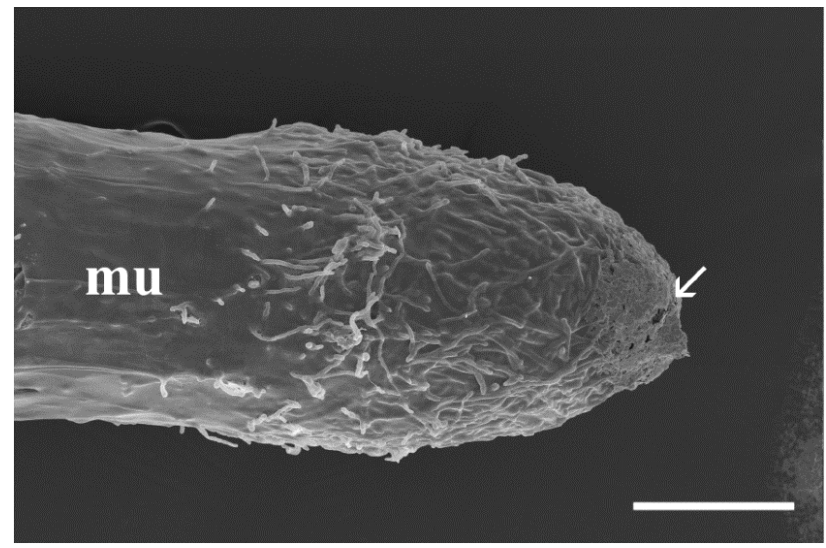

Figure 3 - Scanning electron micrograph of rhizomorph tip of Armillaria gallica. A protective cup of mucilage (arrow) is localized to the tip, and a mucilaginous sheath (mu) covers the entire length of the rhizomorphs. Scale bar $=100 \mu \mathrm{m}$ (from Yafetto et al. 2009).

Jennings \& Watkinson (1982) compared initial stages of mycelial cord development of $S$. lacrymans in culture with the structure of mature strands from infected wood, and reported that cultures with mycelial cords stained with $1 \%$ Nile blue at early stages of development had three types of differentiated hyphae: (i) approximately $10 \mu \mathrm{m}$ diameter wide, empty aseptate hyphae that stained evenly blue; (ii) non-stained, septate hyphae with visible cytoplasmic contents and (iii) narrow and septate unbranched tendril hyphae with dark-stained dense cytoplasm of about $2 \mu \mathrm{m}$ diameter. Meanwhile, a comparative transmission electron microscopy (TEM) and scanning electron microscopy (SEM) studies by Jennings \& Watkinson (1982) of mature mycelial cords of 
S. lacrymans obtained from an actively growing colony in a house revealed three distinguishable regions: (i) an outer surface covered by colorless thin-walled hyphae growing separately from one another; (ii) a zone lying beneath the outer surface characterized by a few hyphae that were cracked with holes; and (iii) a central portion characterized by longitudinal channels.

\section{Rhizomorphs of Armillaria spp}

Granlund et al. (1984) studied A. mellea rhizomorphs with SEM to investigate their internal and external features in relation to their reputed ability to translocate water and other solutes over long distances. The internal structure revealed the arrangement of hyphal tissues of different zones of the A. mellea rhizomorphs as follows: (i) peripheral hyphae that formed a layer approximately between 20 and $30 \mu \mathrm{m}$ thick, (ii) cortical hyphae, (iii) medulla hyphae and (iv) the central space, usually occupied by a cottony pith of fine, loosely-woven hyphae. Furthermore, Granlund et al. (1984) reported that the diameter of the hyphae constituting the various tissues in A. mellea increased towards the center of the rhizomorph. They recorded $2.2 \mu \mathrm{m}, 2.3 \mu \mathrm{m}$, and $13.9 \mu \mathrm{m}$ as the mean diameter of peripheral hyphae, cortical hyphae and medulla hyphae of the rhizomorph, respectively. In addition, the distance between septa of hyphae increased towards the center; for example, while a distance of $20 \mu \mathrm{m}$ between septa was recorded in the cortex, a $70 \mu \mathrm{m}$ distance was recorded between septa in the medulla zone.

Yafetto et al. (2009) confirmed similar zones of hyphal tissues within A. gallica rhizomorphs which they described from the outside to the inside as follows: (i) an outer layer of peripheral hyphae, (ii) an inner cortical layer of radial hyphae, (iii) a medulla region, consisting of two layers of longitudinal hyphae - an outer layer of thick-walled, narrow lumen, tightly packed hyphae, and an inner layer of thin-walled, wide lumen, loosely packed hyphae usually called the vessel hyphae; and (iv) a central cavity (Fig. 4). Yafetto et al. (2009) concluded that indeed A. gallica has wellorganized rhizomorphs characterized by strikingly arranged hyphal types. These descriptions of the hyphal tissues have undoubtedly provided more insight into the structure of rhizomorphs, which further help to elucidate their functions as organs for the translocation and transportation of nutrients and water along their lengths towards their tips. Not only did Yafetto et al. (2009) confirm findings of Granlund et al. (1984) about the structure of A. gallica rhizomorphs, but their study also provided better micrographs from their SEM studies, and comprehensively revised terminologies used to identify the different hyphal types, based on their arrangement, to assuage the usual confusion that normally associated rhizomorphs with their descriptions.

\section{Rhizomorph structure and function}

It is suggested that the central cavity described in Fig. 4 and those previously mentioned in studies by Granlund et al. (1984) are used as air-conducting channels, and may be generated as a result of the collapse of vessel hyphae (Fig. 5), supporting the views of Hartig \& van Tubeuf (1902), Falck (1912). The arrangement of the different hyphae within a rhizomorph is of importance to the translocation in rhizomorph-forming fungi since an aseptate lumen is required for mass translocation of nutrients and water within the vessel hyphae towards the rhizomorph tip, with less expenditure of energy in the form of the application of pressure. This may also suggest why vessel hyphae are thinly walled to allow easy passage of water and osmolytes across the wall surface (Fig. 5). Eamus et al. (1985) provided evidence that supports the view that long-distance translocation in mycelial cord and rhizomorphs occurred predominantly by the movement of a solution along the vessel hyphae.

According to Granlund et al. (1984), peripheral hyphae of rhizomorphs could serve as a source of infection in plants, such that these infective hyphae could be used by A. mellea to make contact and invade new plant hosts, particularly through the roots. Granlund et al. (1984) further argued that the peripheral hyphae may also serve absorptive role for the rhizomorph such that they may constantly supply the rhizomorph with nutrients and water to support its active tip growth; they explained that as the tip extends, the peripheral hyphae, which provides a large surface area in the mature region, may have the potential to laterally absorb nutrient and water from the immediate 
surroundings of the rhizomorph into its interior. The dissolved nutrients and water are thus transported into the inner medulla region for translocation to the tip. Yafetto et al. (2009) suggested that with such intake of nutrients and water, and the accumulation of osmolytes, an internal turgor pressure is created within the rhizomorph, which is eventually converted into the driving force for the growing tip to invade hard, compact substrates.

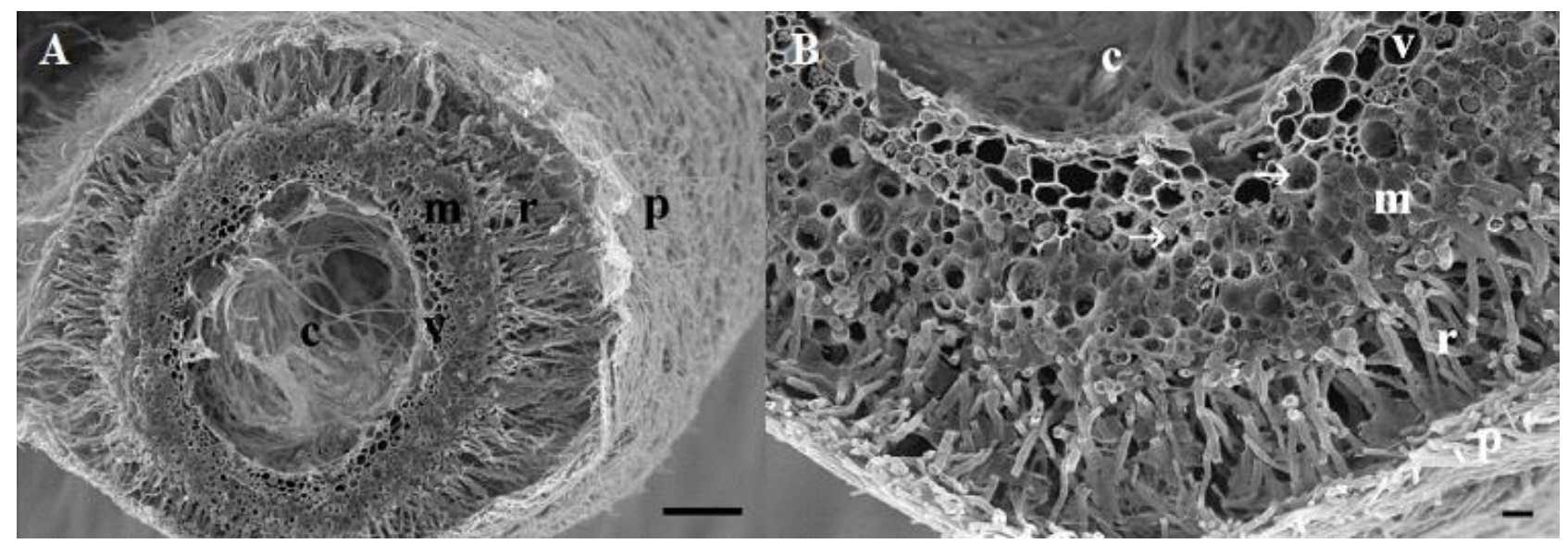

Figure 4 - Scanning electron micrograph of transverse sections of freeze-fractured rhizomorph of Armillaria gallica. A Complete arrangement of hyphae in rhizomorph. B A close up micrograph of hyphal arrangement: From the outer layer to the inner zones are; a cortical layer of loosely-packed, radially arranged, thin hyphae (r), covered with peripheral hyphae (p); an inner medulla of tightlypacked, longitudinally arranged, thick-walled hyphae with narrow lumens $(\mathrm{m})$ with cellular contents (arrows); longitudinally arranged thin-walled vessel hyphae with wide lumens (v), and a central cavity that may be formed by degeneration of vessel hyphae (c). Scale bar $=100 \mu \mathrm{m}(\mathrm{A})$; Scale bar $=10 \mu \mathrm{m}$ (B) (from Yafetto et al. 2009).

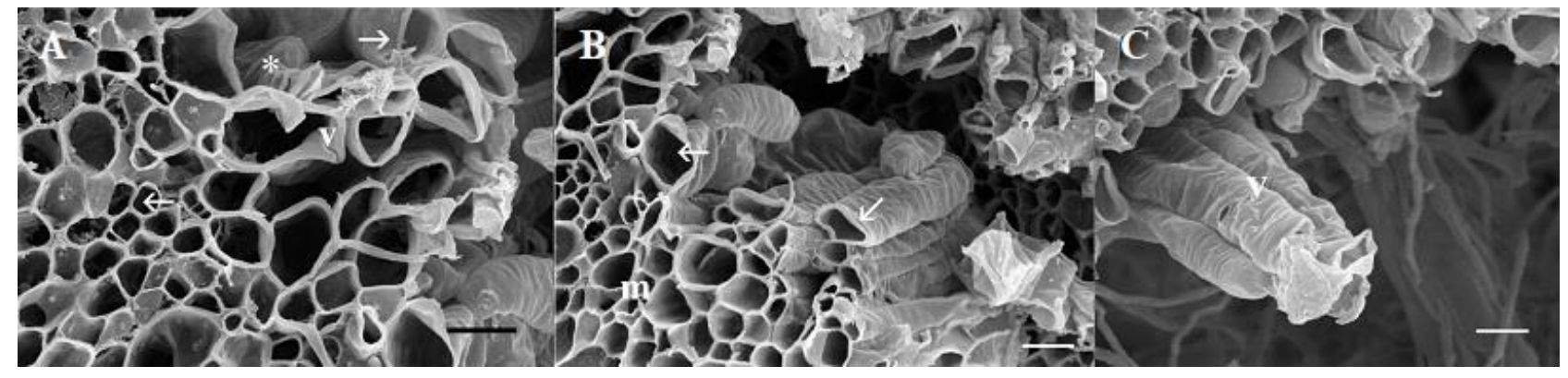

Figure 5 - Scanning electron micrographs of Armillaria gallica rhizomorph. A Vessel hypha (v) in close association with tightly packed longitudinal hyphae (Arrow $\leftarrow$ ). Some of the vessel hyphae have wrinkled wall $(*)$, while others have collapsing wall (Arrow $\rightarrow$ ). Scale bar $=10 \mu \mathrm{m}$. B Wide lumen vessel hyphae (arrows) in close association with narrow lumen, thick-walled longitudinal hyphae $(\mathrm{m})$ that form a rind around the vessel hyphae. Scale bar $=10 \mu \mathrm{m}$. (C) Wrinkled, collapsed vessel hyphae (v), protruding from the freeze-fractured surface. Scale bar $=10 \mu \mathrm{m}$ (Micrographs courtesy of L. Yafetto).

\section{Armillaria: A model system for the study of fungal rhizomorphs}

The genus Armillaria (Fr.: Fr) is a cosmopolitan pathogenic basidiomycete that contains about 40 species known for causing root and butt rot diseases (Watling et al. 1991, Volk \& Burdsall 1995, Pegler 2000, Baumgartner et al. 2011). The term "honey fungus" has been used to describe many species of Armillaria because of its yellowish caps and the sweet taste of their mushrooms. Armillaria has a wide range of hosts including deciduous and coniferous trees, shrubs, and vines (Smith et al. 1992), and it is considered one of the most devastating disease-causing plant 
pathogens; it kills and decomposes plants in forests and plantations in both temperate and tropical regions of the world (Garraway et al. 1991).

Of all species of the genus Armillaria, A. mellea is the most pathogenic, and the best studied. Other species, including A. luteobubalina and A. ostoyea, have also been reported to be pathogenic (Fox 2000). A. mellea, like other Armillaria species has the ability to produce reddish- to blackcolored rhizomorphs, which have a unique internal structure (Townsend 1954).

Interestingly, the mycelium and rhizomorphs of some Armillaria species have been studied over a century and are shown to be bioluminescent, but, surprisingly, not their fruiting bodies (Murrill 1915, Buller 1924, Harvey 1952, Wassink 1978, Mihail \& Bruhn 2007).

As a root pathogen, the direct control of Armillaria spp is practically impossible to accomplish, but they are easily detected in the terrestrial environment, since they occur everywhere in the soil; they produce fruiting bodies at the base of a tree trunk as well as black rhizomorphs that are found beneath forest leaf litter and in association with roots of forest trees (Fox 1990, Schmidt 2006). In 1992, for example, Smith et al. (1992) detected A. bulbosa in Michigan using molecular genetics techniques. The A. bulbosa was reported to have occupied an area of 15 hectares, weighed about $10,000 \mathrm{~kg}$ and was more than 1,500 years old, making it one of the largest and oldest living organisms ever known. Similarly, clones of A. ostoyae and A. gallica have been detected in soils in Oregon (USA) and England to have colonized an area over $9 \mathrm{~km}^{2}$ and 9 hectares, respectively (Marximüller \& Holdenrieder 2000).

In most cases, Armillaria is a saprobe, colonizing dead tree stumps, but it becomes parasitic, either as a necrotroph or biotroph when it infects the roots of a healthy host using its networks of rhizomorphs (Watling et al. 1991, Baumgartner et al. 2011, Tsykun et al. 2012). A rhizomorph adheres firmly to root tips of healthy plants after the mucilaginous material on its tip dries, sends out mycelia and continues to grow and spread beneath the bark of the tree producing mycelial fan. Competition from neighboring trees, insect attack and the prevalence of adverse climatic factors further affect the health of the infected host. In such a compromised condition, the host is killed outright if it fails to successfully defend itself and the mycelium manages to reach the xylem to interfere with the flow of sap in the cambium (Wahlström \& Johansen 1992, Woodward 1992, Schmidt 2006). Thus, rhizomorphs are used by Armillaria as a means to propagate itself to effect infection in other healthy trees over long distances (Hartig 1874, Garrett 1970).

Above all, the genus Armillaria, unlike other rhizomorph-producing genera (Meruliporia incrassata and Serpula lacrymans), readily produces rhizomorphs in vitro making it a suitable candidate as a model system to further study fungal rhizomorphs (Yafetto et al. 2009). Additionally, Armillaria spp. have been well studied in North America and Europe, but sparingly in Africa, and findings from such studies are well represented in literature, some of which are presented in Table 1.

\section{Mycelial cords and rhizomorphs: dry rot by Meruliporia incrassata and Serpula lacrymans}

The rhizomorph-forming fungus Meruliporia incrassata causes dry rot of wooden components in buildings. Its damage is sometimes referred to as brown-rot. Since its description from pine as Merulius incrassatus Berk. \& Curt. in South Carolina, M. incrassata (Berk \& Curtis.) Murr. (Family Coniophoraceae) has been recognized as a wood-decay fungus in North America (Berkley \& Curtis 1849). It has a wide distribution in the southeastern United States of America and has been reported occasionally in Canada (Verall 1968, Palmer \& Eslyn 1980). Its occurrence in the southern British Columbia, Canada is an interesting observation, since this region is very moist. There has been no report of the occurrence of $M$. incrassata in Arizona or New Mexico, an observation attributed to the dry climate of the desert in the southwest USA. Its distribution pattern suggests that $M$. incrassata develops best in warm climates (Burdsall 1991).

M. incrassata causes severe damage to homes in California using its rhizomorphs (Fig. 6). During attacks on homes, $M$. incrassata develops rhizomorphs from its depleted food base mostly from outside the home (tree stumps, landscaping lawns with woodchips, etc.). The rhizomorph is capable of translocating nutrients and water, under warm and moist conditions, to its tip until it 
encounters a wooden component of the building. It then begins to colonize the wood swiftly by digesting and extracting cellulose, leaving behind the brown lignin component of the wood. The description of $M$. incrassata as a dry rot fungus can, therefore, be regarded as erroneous because its participation in wood decomposition is impossible without water. $M$. incrassata fungus destroys dry wood by transferring water through its rhizomorphs to the sites of active growth and decomposition (Verall 1968, Brownlee \& Jennings 1981a, b).

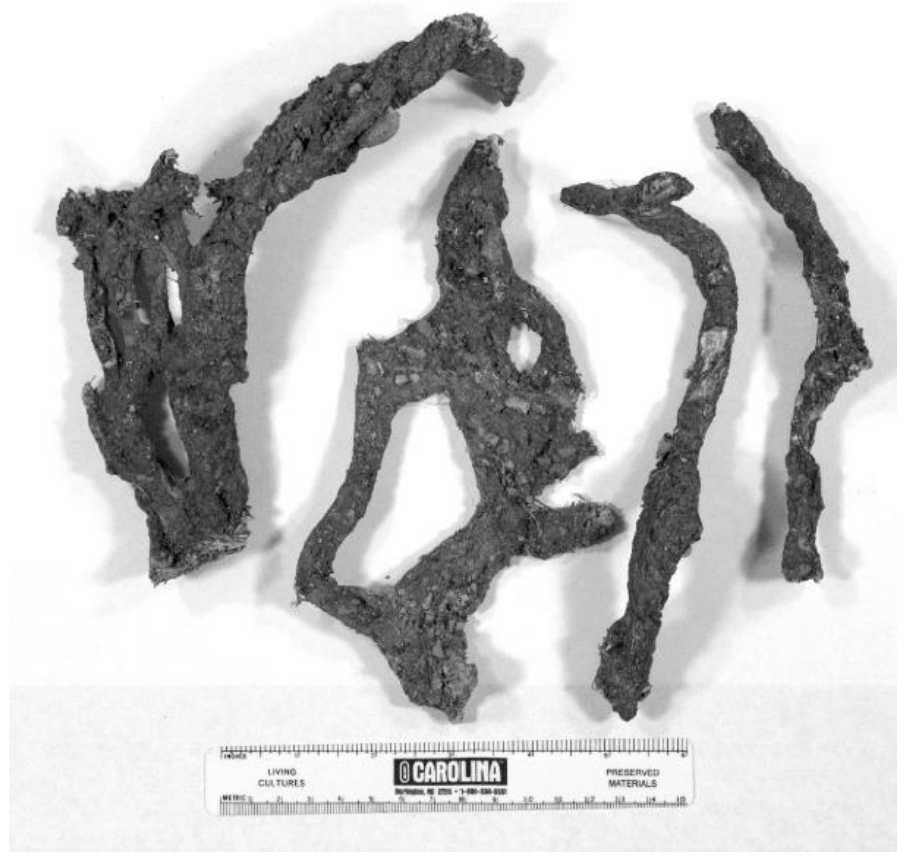

Figure 6 - Field-collected rhizomorphs of Meruliporia incrassata from an infested home in California. Note the root-like, woody appearance (Specimen courtesy Luis De La Cruz Wood Preservation Services, Pasadena, CA, USA; Photo courtesy of L. Yafetto).

Possible conditions for infestations of homes in California by $M$. incrassata may include the following: first, when lands are cleared of trees for construction of homes, tree stumps are sometimes left in the soil. An array of fungi colonizes these tree stumps until the nutrients are depleted, at which time rhizomorph-forming species develop rhizomorphs in search of new sources of food; second, topsoil and wood mulch used in landscaping may often provide a combination of optimum conditions (moisture and poor ventilation) for wood-decay fungi to develop rhizomorphs. This second condition normally results from the continuous supply of water by sprinklers under low nutrient conditions. As long as the fungus has the continuous supply of water and can channel it to the tips of its rhizomorphs, it survives until it locates a nutrient-rich substrate in the building; third, an untreated wood used to construct buildings is another potential source of M. incrassata growth and rhizomorph development. Under all these conditions, the destructive abilities of the rhizomorphs manifest themselves when they contact wooden components of a building (Money 2004).

Meanwhile, a different fungal species, Serpula lacrymans, is known to be responsible for similar destruction in Europe (especially in Britain), and other parts of the world, including Japan and Australia (Money 2004). For example, S. lacrymans, together with other fungi, caused enormous historical damage to wood in ships, where in one instance, rotting of timber was responsible for sinking the ship Royal George in 1782 and necessitated rebuilding of Queen Charlotte in 1810 (Money 2004).

Both $M$. incrassata and S. lacrymans produce brown basidiomes, with brown, thick-walled, dextrinoid basidiospores; both cause brown rot of their wood substrates; both produce water- and nutrient-conducting rhizomorphs and mycelial cords, respectively (Burdsall 1991, Moore 1994). 
Table 1 Selected relevant literature highlighting some key studies of Armillaria spp and rhizomorphs.

\begin{tabular}{ll}
\hline Area of Study & Reference \\
\hline Development/Distribution & Snider 1959, MacDonald \& Cartter 1961, Weinhold 1963, \\
& Motta 1967, 1969, Went 1973, Motta \& Peabody 1982, \\
& Eamus et al. 1985, Cairney et al. 1988b, Masuka 1989, \\
& Twery et al. 1990, Gray et al. 1996, Horner et al. 1995, Volk \\
& et al. 1996, Tsopelas \& Tjamos 1999, Baumgartner \& Rizzo \\
& 2001, Mansilla et al. 2001, Otieno et al. 2003, Prange \& \\
& Nelson 2006, Freymann 2008, Baumgartner et al. 2011
\end{tabular}

Ecology

Garrett 1953, 1960, Masuka 1989, Rizzo et al. 1990, Horner et al. 1995, Isaac 1995, Tsopelas \& Tjamos 1999, Wallander et al. 2002, Prange \& Nelson 2006, Rigling et al. 2006, Vargas \& Allen 2008a, 2008b, Freymann 2008, Tsykun et al. 2012, Kubiak et al. 2017

Forest pathology

Garrett 1953, 1956, 1960, Gibson 1960, Azevedo 1976, Rishbeth 1978, Thompson \& Boddy 1983, Twery et al. 1990, Tsopelas \& Tjamos 1999, Coetzee et al. 2000, Wallander et al. 2002, Morrison 2004, Treseder et al. 2005, Vargas \& Allen 2008b, Baumgartner et al. 2011

\section{Molecular Characterization/ Phylogeny/Taxonomy/Systematics}

Korhonen 1978, Anderson \& Ullrich 1979, Guillaumin et al. 1985, Roll-Hansen 1985, Anderson 1986, Motta \& Korhonen 1986, Termorshuizen \& Arnolds 1987, Watling et al. 1991, Volk \& Burdsall 1995, Volk et al. 1996, Zolciak et al. 1997, Ota et al. 1998, Coetzee et al. 2000, 2001, 2003, Qin et al. 2007, Tsykun et al. 2013

\section{Future perspectives}

Rhizomorphs and mycelial cords continue to play vital roles in the survival, propagation, and pathogenicity of fungi, and, as such, interest in their study should be intensified and sustained. Professor Lynne Boddy of Cardiff University, UK, and her collaborators, over the years, have extensively studied mycelial strands and cords, and have produced insightful findings of the structure, functions, and behavior of mycelial cords which (Fricker et al. 2017). To this end, some specific areas of biomechanics of Armillaria rhizomorphs need urgent attention. Armillaria species remain a well-studied group, but their rhizomorphs are excellent models for such biomechanical studies (Yafetto et al. 2009), and remain inadequately studied by mycologists and plant pathologists.

M. incrassata continues to remain one of the best candidates for rhizomorph studies, because, although it is known to produce rhizomorphs, there is no information in the literature on its ability to produce in vitro rhizomorphs with organized tip growth as seen in Armillaria. This necessitates a renewed interest in the study of in vitro production of rhizomorph in $M$. incrassata, the success of which shall be a breakthrough in rhizomorph studies.

Since data on profiled gene sequence of Armillaria already exist, work to identify genes that control the growth and development of rhizomorphs should be initiated. This can be extended to other rhizomorph-producing fungi, particularly $M$. incrassata for comparative purposes. There is a 
good prospect for understanding the molecular basis of these processes in Armillaria and Meruliporia that will eventually guide the development of effective control strategies in the future.

As a crucial step, investigations that seek to address key aspects of the biomechanics of rhizomorphs should adopt a multidisciplinary approach. This multidisciplinary approach is critical since there are biological, molecular, physical and mathematical components necessary for better understanding of rhizomorph growth, development and invasive behavior.

\section{Acknowledgments}

The author is grateful to the Department of Botany, Miami University, Ohio, USA, for providing funds through the Academic Challenge Grant towards the study of rhizomorphs. The author is equally indebted to Professor Nicholas P. Money (Miami University, Ohio, USA), Dr. Dana Richter (Michigan Technological University, Michigan, USA), Dr. Diana J. Davis (College of Mount St. Joseph, Ohio, USA), and Dr. Richard T. Taylor (Miami University, Ohio, USA), for their diverse contributions to advance the study of rhizomorphs. I also thank Dr. Richard E. Edelmann and Matthew Duley of the Center for Advanced Microscopy and Imaging at Miami University, USA, for their expert advice on studying rhizomorph structures with scanning electron microscopy.

\section{References}

Anderson JB, Ullrich RC. 1979 - Biological species of Armillaria mellea in North America. Mycologia 71, 402-414.

Anderson JB, Ullrich RC. 1982 - Translocation in rhizomorphs of Armillaria mellea. Experimental Mycology 6, 31-40.

Anderson JB. 1986 - Biological species of Armillaria in North America: redesignation of groups IV and VIII and enumeration of voucher strains for other groups. Mycologia 8, 837-839.

Arora D. 1986 - Mushroom Demystified: A Comprehensive Guide to the Fleshy Fungi. Ten Speed Press, Berkeley.

Azevedo NFS. 1976 - Significance of rhizomorph formation of Armillaria mellea (Fr.) Kum. on Cryptomeria japonica (L.f.) D. Don in the Azores. Phytopathologia Mediterranea 15, 73-77.

Baumgartner K, Rizzo DM. 2001 - Distribution of Armillaria species in California. Mycologia 93, 821-830.

Baumgartner K, Coetzee MPA, Hoffmeister D. 2011 - Secrets of the subterranean pathosystems of Armillaria. Molecular Plant Pathology 12, 515-534.

Berkley MJ, Curtis MA. 1849 - Decades of fungi XXIII and XXIV. North and South Carolina. Hooker's Journal of Botany 1, 234-239.

Brownlee C, Jennings DH. 1981a - Further observations on tear or drop formation by mycelium of Serpula lacrymans. Transactions of the British Mycological Society 77, 33-40.

Brownlee C, Jennings DH. 1981b - The content of soluble carbohydrates and their translocation in mycelium of Serpula lacrymans. Transactions of the British Mycological Society 77, 615619.

Brundrett MC, Tedersoo L. 2018 - Evolutionary history of mycorrhizal symbioses and global host plant diversity. New Phytologist, doi:10.111/nph.14976.

Buller AHR. 1924 -Researches on Fungi. Volume 3. Longmans, London.

Burdsall HH. 1991 - Meruliporia (Poria) incrassata: Occurrence and significance in the United States as a dry rot fungus. In: Jennings DH and Bravery AF (eds.), Serpula lacrymans: Fundamental Biology and Control Strategies. John Wiley \& Sons, Chichester, UK. pp. 189191.

Butler GM. 1957 - The development and behavior of mycelial strands in Merulius lacrymans (Wulf.) Fr. I. Strand development during growth from a food-base through a non-nutrient medium. Annals of Botany 21, 523-537.

Butler GM. 1958 - The development and behavior of mycelial strands in Merulius lacrymans (Wulf.) Fr. I. Hyphal behavior during strand formation. Annals of Botany 22, 219-236. 
Butler GM. 1966 - Vegetative structures in the fungi. In: Ainsworth GC and Sussman AS (eds.), the Fungi. Academic Press, London, U.K.

Cairney JWG. 1992 - Translocation of solutes in ectomycorrhizal and saprotrophic rhizomorphs. Mycological Research 96, 135-141.

Cairney JWG, Jennings DH, Ratcliffe RG, Southon TE. 1988a - The physiology of basidiomycete linear organs. II. Phosphate uptake by rhizomorphs of Armillaria mellea. New Phytologist 109, 327-333.

Cairney JWG, Jennings DH, Veltkamp CJ. 1988b - Structural differentiation in maturing rhizomorphs of Armillaria mellea (Tricholomatales). Nova Hedwigia 46, 1-25.

Carlile MJ. 1994 - The success of the hypha and mycelium. In: Gow ARN and Gadd GM (ed.) The Growing Fungus. Chapman and Hall, London.

Coetzee MPA, Wingfield BD, Coutinho TA, Wingfield MJ. 2000 - Identification of the causal agent of Armillaria root rot of Pinus species in South Africa. Mycologia 92, 777-785.

Coetzee MPA, Wingfield BD, Bloomer P, Ridley GS et al. 2001 - Phylogenetic relationships of Australian and New Zealand Armillaria species. Mycologia 93, 887-896.

Coetzee MPA, Wingfield BD, Bloomer P, Ridley GS, Wingfield MJ. 2003 - Molecular identification and phylogeny of Armillaria isolates from South America and Indo-Malaysia. Mycologia 95, 285-293.

Eamus D, Thompson W, Cairney JWG, Jennings DH. 1985 - Internal structure and hydraulic conductivity of basidiomycete translocating organs. Journal of Experimental Botany 36, $1110-1116$.

Eriksson K-EL, Blanchette RA, Ander P 1990 - Microbial and enzymatic degradation of wood and wood components. Springer, Berlin Heidelberg New York.

Falck R. 1912 - Die merulius-fäule des bauholzes. Hausschwamm Forschungen 6, 1-405.

Fox RTV. 1990 - Diagnosis and control of Armillaria honey fungus root rot of trees. Profess Horticult 4, 121-127.

Fox RTV. 2000 - Armillaria Root Rot: Biology and Control of Honey Fungus. Intercept Limited, Andover.

Freymann BP. 2008 - Physical properties of fungal rhizomorphs of marasmioid basidiomycetes used as nesting material by birds. International Journal of Avian Science 150, 395-399.

Fricker MD, Heaton LLM, Jones NS, Boddy L. 2017 - The mycelium as a network. Microbiology Spectrum 5 (3), 10.1128/microbiolspec.FUNK-0033-2017 file.

Garraway MO, Hüttermann A, Wargo PM. 1991 - Ontology and physiology. In: Shaw GC and Kile GA (eds.), Armillaria Root Disease. United States Department of Agriculture-Forest Service Agriculture Handbook No. 691. pp. 21-46.

Garrett SD. 1953 - Rhizomorph behavior in Armillaria mellea (Vahl.) Quél. I. Factors controlling rhizomorph initiation by A. mellea in pure culture. Annals of Botany 17, 63-79.

Garrett SD. 1956 - Rhizomorph behavior in Armillaria mellea (Vahl.) Quél. II. Logistics of infection. Annals of Botany 20, 193-209.

Garrett SD. 1960 - Rhizomorph behavior in Armillaria mellea (Fr.) Quél. III. Saprophytic colonization of woody substrates in soil. Annals of Botany 24, 275-285.

Garrett SD. 1963 - Soil fungi and soil fertility. Pergamon Press, Oxford.

Garrett SD. 1970 - Pathogenic root-infecting fungi. Cambridge University Press, Cambridge.

Garrett SD. 1981 - Soil and soil fertility: an introduction to soil mycology ( ${ }^{\text {nd }}$ Ed). Pergamon Press, Oxford.

Gerdemann JW. 1968 - Vesicular-arbuscular mycorrhiza and plant growth. Annual Review of Phytopathology 6, 397-418.

Gibson IAS. 1960 - Armillaria root rot in Kenya pine plantations. Empire Forestry Review 39, $94-$ 99.

Goodell B. 2003 - Brown rot degradation of wood: our evolving view. In: Goodell B, Nicholas D, Schultz TP (eds) Wood deterioration and preservation: advances in our changing world. Oxford: American Chemical Society Series, Oxford University Press, pp. 97-118. 
Goodell B, Zhu Y, Kim S, Kafle K et al. 2017 - Modification of nanostructure of lignocellulose cell walls via a non-enzymatic lignocellulose deconstruction system in brown rot wood-decay fungi. Biotechnology for Biofuels 10, 179-193.

Granlund HI, Jennings DH, Veltkamp K. 1984 - Scanning electron microscope studies of rhizomorphs of Armillaria mellea. Nova Hedwigia 39, 85-100.

Granlund HI, Jennings DH, Thompson W. 1985 - Translocation of solutes along rhizomorphs of Armillaria mellea. Transactions of the British Mycolological Society 84, 111-119.

Gray SN, Dighton J, Jennings DH. 1996 - The physiology of basidiomycete linear organs. III. Uptake and translocation of radiocaesium within different mycelia of Armillaria ssp. growing in microcosm and in the field. New Phytologist 132, 471-482.

Guillaumin JJ, Lung B, Romagnesi H, Marxmüeller H. 1985 - Systematique des Armillaires du groupe Mellea. Consequences phytopathologiques. European Journal of Forest Pathology 15, $268-277$.

Hartig R. 1873 - Vorläufige Mitteilung über den Parasitismus von Agaricus melleus und dessen Rhizomorphen. Bot. Ztg. 31, 295-297.

Hartig R. 1874 - Wichtige Krankheiten der Waldbäume. Beiträge zur mycologie und Phytopathology für Botaniker und Forstmänner. Berlin: Springer. 127 p. [Important Diseases of Forest Trees. Contributions to Mycology and Phytopathology for Botanists and Foresters. Phytopathological Classics No. 12; 1975. St. Paul, MN: American Phytopathological Society.]

Hartig R, van Tubeuf CF. 1902 - Der echte Hausschwamm und andere das Bauholz zerstörende Pilze. Berlin: Springer-Verlag.

Harvey EN. 1952 - Bioluminescence. Academic Press, New York.

Highley TL, Illman BL. 1991 - Progress in understanding how brown-rot fungi degrade cellulose. Biodet Abstr 5, 231-244.

Horner HT, Tiffany LH, Knaphus G. 1995 - Oak-leaf-litter rhizomorphs from Iowa and Texas: Calcium oxalate producers. Mycologia 87, 34-40.

Hornung U, Jennings DH. 1981 - Light and electron microscopical observations of surface mycelium of Serpula lacrymans: Stages of growth and hyphal nomenclature. Nova Hedwigia 34, 101-126.

Isaac S. 1995 - What are fungal cords, strands and rhizomorphs and how are they of benefit to the fungus? Mycologist 9, 90-91.

Jennings DH, Thornton JD, Galpin MFJ, Coggins CR. 1974 - Translocation in fungi. In: Sleigh MA and Jennings DH (eds), Transport at the Cellular Level. Symposium of the Society for Experimental Biology. Vol. 28, Cambridge University Press, Cambridge. pp. 139-156.

Jennings DH. 1987 - Translocation of solutes in fungi. Biological Review 62, 215-243.

Jennings L, Watkinson SC. 1982 - Structure and development of mycelial strands in Serpula lacrymans. Transactions of the British Mycological Society 78, 465-474.

Jennings DH. 1991 - The physiology and biochemistry of the vegetative mycelium. In: Jennings DH and Bravery AF (eds.), Serpula lacrymans: Fundamental Biology and Control Strategies. John Wiley \& Sons, Chichester, UK. pp. 55-79.

Korhonen K. 1978 - Interfertility and clonal size in the Armillariella mellea complex. Karstenia 18, $31-42$.

Kubiak K, Zólciak A, Damszel M, Lech P, Sierota Z. 2017 - Armillaria pathogenesis under climate changes. Forests 8, 100.

Lindahl BD, Olsson S. 2004 - Fungal translocation-creating and responding to environmental heterogeneity. Mycologist 18, 79-88.

Lekberg Y, Rosendahl S, Olsson PA. 2015 - The fungal perspective of arbuscular mycorrhizal colonization in 'nonmycorrhizal' plants. New Phytologist 205, 1399-1403.

MacDonald JA, Cartter MA. 1961 - The rhizomorphs of Marasmius androsaceus Fries. Transactions of the British Mycological Society 44, 72-78. 
Mansilla JP, Aguín O, Sainz MJ. 2001 - A fast method for production of Armillaria inoculum. Mycologia 93, 612-615.

Marximüller H, Holdenrieder O. 2000 - Morphologie und populationsstruktur der beringten Arten von Armillaria s.1. Mycologia Bavarica 4, 9-32.

Masuka A. 1989 - The incidence of Armillaria root and butt diseases in Pinus spp. plantations in Zimbabwe. The Commonwealth Forestry Review 68, 121-124.

Mihail JD, Bruhn JN. 2007 - Dynamics of bioluminescence by Armillaria gallica, A. mellea and A. tabescens. Mycologia 99, 341-350.

Money NP. 2004 - Carpet Monsters and Killer Spores: A Natural History of Toxic Mold. Oxford University Press, New York. pp. 127-142.

Moore D. 1994 - Tissue formation. In: Neil AR and Gadd GM (eds.), The Growing Fungus Chapman \& Hall, London, pp. 423-465.

Morrison DJ. 2004 - Rhizomorph growth habit, saprophytic ability and virulence of 15 Armillaria species. Forest Pathology 34, 15-26.

Mosse B. 1973 - Advances in the study of vesicular-arbuscular mycorrhiza. Annual Review of Phytopathology 11, 171-196.

Motta JJ. 1967 - A note on the mitotic apparatus in the rhizomorph meristem of Armillaria mellea. Mycologia 59, 370-375.

Motta JJ. 1969 - Cytology and morphogenesis in the rhizomorph of Armillaria mellea. American Journal of Botany 56, 610-619.

Motta JJ, Peabody DC. 1982 - Rhizomorph cytology and morphogenesis in Armillaria tabescens. Mycologia 74, 671-674.

Motta JJ, Korhonen K. 1986 - A note on Armillaria mellea and Armillaria bulbosa from the Middle Atlantic States. Mycologia 78, 471-474.

Murrill WA. 1915 - Luminescence in fungi. Mycologia 7, 131-133.

Nuss I, Jennings DH, Veltkamp CJ. 1991 - Morphology of Serpula lacrymans. In: Jennings DH, and Bravery AF (eds.), Serpula lacrymans: Fundamental Biology and Control Strategies, John Wiley \& Sons, Chichester, UK. pp. 9-38.

Ota Y, Matsushita N, Nagasawa E, Terashita T et al. 1998b - Biological species of Armillaria in Japan. Plant Disease 82, 537-543.

Otieno W, Sierra AP, Termorshuizen A. 2003 - Characterization of Armillaria isolates from tea (Camellia sinensis) in Kenya. Mycologia 95, 160-175.

Palmer JG, Eslyn WE. 1980 - Monographic information on Serpula (Poria) incrassata. International Group on Wood Preservation, Doc. Nr. IRG/WP/160. p. 60.

Pegler D. 2000 - Taxonomy, nomenclature and description of Armillaria. In: Fox RTV (ed.), Armillaria Root Rot: Biology and Control of Honey Fungus. Intercept Limited, Andover pp. 81-110.

Prange S, Nelson DH. 2006 - Use of fungal rhizomorphs as nesting material by Glaucomys volans (Southern flying squirrels). Southeastern Naturalist 5, 355-360.

Qin GF, Zhao J, Korhonen K. 2007 - A study on intersterility groups of Armillaria in China. Mycologia 99, 430-441.

Rayner ADM, Powell KA, Thompson, W, Jennings DH. 1985 - Morphogenesis of vegetative organs. In: Moore D, Casselton LA, Wood DA, and Frankland JL (eds.), Developmental Biology of Higher Fungi. Cambridge University Press, Cambridge, pp 249-279.

Rigling D, Günthardt-Goerg MS, Blauenstein H, Frey B. 2006 - Accumulation of heavy metals into Armillaria rhizomorphs from contaminated soils. Forest Snow and Landscape Research 80, 213-220.

Rishbeth J. 1968 - The growth rate of Armillaria mellea. Transactions of the British Mycological Society $51,575-586$.

Rishbeth J. 1978 - Infection foci of Armillaria mellea in firstrotation hardwoods. Annals of Botany 42, 1131-1139. 
Ritschkoff AC, Pere J, Buchert J, Viikari L. 1992 - The role of oxidation in wood degradation by brown-rot fungi. IRG/WP/1562.

Rizzo DM, Smereka KJ, Harrington TC. 1990 - Notes on the rhizomorphs and mating systems of Xeromphalina campanella. Mycologia 82, 651-655.

Rogers CH, Watkins GM. 1938 - Strand formation in Phymatotrichum omnivorum. American Journal of Botany 25, 244-246.

Roll-Hansen, F. 1985 - The Armillaria species in Europe: a literature review. European Journal of Forest Pathology 15, 22-31.

Schmidt O. 2006 - Wood and Tree Fungi: Biology, Damage, Protection, and Use. Springer-Verlag Berlin Heidelberg, p. 189.

Schwarze FWMR. 2007 - Wood decay under the microscope. Fungal Biology Reviews 21, 133170.

Smith ML, Bruhn JN, Anderson JB. 1992 - The fungus Armillaria bulbosa is among the largest and oldest living organisms. Nature 356, 428-431.

Snider PJ. 1959 - Stages of development in rhizomorphic thalli of Armillaria mellea. Mycologia 51, 693-707.

Termorshuizen A, Arnolds E. 1987 - On the nomenclature of the European species of the Armillaria mellea group. Mycotaxon 30, 101-116.

Thompson W, Boddy L. 1983 - Decomposition of suppressed oak trees in even-aged plantations. III. Colonization of tree roots by cord- and rhizomorph-producing basidiomycetes. New Phytologist 93, 277-291.

Thompson W. 1984 - Distribution and functioning of mycelial cord systems of decomposer basidiomycetes of the deciduous woodland floor. In: Jennings DH and Rayner ADM (eds.), The Ecology and Physiology of the Fungal Mycelium. Cambridge University Press, Cambridge, pp. 185-214.

Townsend BB. 1954 - Morphology and development of fungal rhizomorphs. Transactions of the British Mycological Society 37, 222-232.

Treseder KK, Allen FM, Ruess RW, Pregitzer KS, Hendrick RL. 2005 - Lifespans of fungal rhizomorphs under nitrogen fertilization in a pinyon-juniper woodland. Plant and Soil 270, 249-255.

Tsopelas P, Tjamos EC. 1999 - Inoculation studies of olive trees with Armillaria species from Greece. Phytopathologia Mediterranea 38, 132-136.

Tsykun T, Rigling D, Nikolaychuk V, Prospero S. 2012 - Diversity and ecology of Armillaria species in virgin forests in the Ukranian Carpathians. Mycological Progress 11, 403-414.

Tsykun T, Rigling D, Prospero S. 2013 - A new multilocus approach for a reliable DNA-based identification of Armillaria species. Mycologia 105(4), 1059-1076. doi: 10.3852/12-209.

Twery MJ, Mason GN, Wargo PM, Gottschalk KW. 1990 - Abundance and distribution of rhizomorphs of Armillaria spp. in defoliated mixed oak stands in western Maryland. Canadian Journal of Forest Research 20, 674-678.

Vargas R, Allen MF. 2008a - Dynamics of fine roots, fungal rhizomorphs, and soil respiration in a mixed temperate forest: Integrating sensors and observations. Vadose Zone Journal 7, 10551064.

Vargas R, Allen MF. 2008b - Environmental controls and the influence of vegetation type, fine roots and rhizomorphs on diel and seasonal variation in soil respiration. New Phytologist 179, $460-471$.

Verall AF. 1968 - Poria incrassata rot: Prevention and control in buildings. United States Department of Agriculture-Forest Service Technical Bulletin 1385, 1-27.

Volk TJ, Burdsall HH. 1995 - A nomenclatural study of Armillaria and Armillaria species. Synopsis Fungorum Vol. 8. Oslo: Fungiflora. pp 121.

Volk TJ, Burdsall HH, Banik MT. 1996 - Armillaria nabsnona, a new species from Western North America. Mycologia 88, 484-491. 
Wahlström KT, Johansen M. 1992 - Structural responses in bark to mechanical wounding and Armillaria ostoyae infection in seedlings of Pinus sylvestris. Forest Pathology 22, 65-76.

Wallander H, Johansson L, Pallon J. 2002 - PIXE analysis to estimate the elemental composition of ectomycorrhizal rhizomorphs grown in contact with different minerals in forest soil. FEMS Microbiology Ecology 39, 147-156.

Wassink EC. 1978 - Luminescence of fungi. In.: Herring PJ (ed.), Bioluminescence in Action. Academic Press, London, pp. 171-197.

Watkinson SC. 1971 - The mechanism of mycelial strand induction in Serpula lacrymans: a possible effect of nutrient distribution. New Phytologist 70, 1079-1088.

Watkinson SC, Boddy L, Money NP. 2016 - The Fungi (3rd Ed) Academic Press, MA, USA, pp $58-60$.

Watling R, Kile GA, Burdsall HH. 1991 - Nomenclature, taxonomy, and identification. In: Shaw G.C. and Kile, G. A. (eds), Armillaria Root Disease. United States Department of Agriculture-Forest Service Agriculture Handbook No. 691. pp. 1-9.

Weinhold AR. 1963 - Rhizomorph production by Armillaria mellea induced by ethanol and related compounds. Science 142, 1065-1066.

Went FW. 1973 - Rhizomorphs in soil not connected with fungal fruiting bodies. American Journal of Botany 60, 103-110.

Willis A, Rodrigues BF, Harris PJC. 2012 - The ecology of arbuscular mycorrhizal fungi. Critical Reviews in Plant Sciences 32(1), 1-20. Doi:10.1080/07352689.2012.683375

Woodward S. 1992 - Responses of gymnosperm bark tissues to fungal infections. In: Blanchette RS and Biggs AR (eds.), Defense Mechanisms of Woody Plants against Fungi. Springer, Berlin Heidelberg, New York, pp. 62-75.

Yafetto L, Davis DJ, Money NP. 2009 - Biomechanics of invasive growth by Armillaria rhizomorphs. Fungal Genetics and Biology 46 (9), 688-694.

Zolciak A, Bouteville RJ, Tourvieille J, Roeckel-Drevet P, Nicolas P, Guillaumin JJ. 1997 Occurrence of Armillaria ectypa (Fr.) Lamoure in peat bogs of the Auvergne - the reproduction system of the species. Crypt. Mycol. 18, 299-313. 